\title{
Contemporary Rural Buryat Intelligence
}

DOI: 10.31551/2410-2725-2018-4-2-276-288

\section{Zhambalova Sesegma Gendenovna}

Doctor of History, Associate Professor, The Institute for Mongolian, Buddhist and Tibetan Studies of the Siberian Branch of the Russian Academy of Sciences. Russian Federation, Sahyanova str., 6, Ulan-Ude,).E-mail: zhambalovas@yandex.ru

\begin{abstract}
The analysis of empirical materials is carried out on the basis of fundamentally new methodological settings on the identification of contemporary intelligentsia. It made it possible to reveal in contemporary Buryat rural society presence of intelligentsia of the new format which does not coincide with typology known earlier. As a result a new range of people is introduced into this social layer, not previously entered into it. These are Buddhist- laymen who do not have standard higher education, nor special Buddhist education. The process of their ideology formation via special translation of traditions from the knowing old men to the interested young people is shown. This situation is characteristic for the crisis periods of history, and translation of knowledge occurs both in verbal form and with the help of Buddhist books on old-Mongolian written language. These are people with the special psychological type of personality which has been established as a result of small boundary states. It is revealed that this type of people is extended over entire Buryatia. It is shown that women enter into this circle on the same level with the men. Their task is revival of traditional culture elements, including religiosity as the bases of the ethnos survival in the global world. This adherence of people to the interests of its ethnos cannot be carried to ethno nationalism, and should be considered as ethnophilia which assumes concern about retention and development of ethnos, its language and culture. In the article the conclusion is made that in the overall mass of the population this formation of people is not big, however, they play important role in sustainable development of rural society, in retention of ethnic specific character of the small ethnos in the poly-ethnic environment.
\end{abstract}

Keywords: rural society; Buryat Buddhists; intelligentsia; specific character; traditionalism; revival; sustainable development.

\section{Қазіргі заманғы бурят ауыл зиялылары}

\section{Жамбалова Сэсэгма Гэндэновна}

тарих ғылымдарының докторы, доцент, РҒА СБ моңғолтану, Буддология және тибетология институтының жетекші ғылыми қызметкері. Ресей Федерациясы, 670047, Улан-Удэ қ, ул. Сахьянова к, 6 үй. E-mail: zhambalovas@yandex.ru

\begin{abstract}
Андатпа. Осы мақалада қазіргі заманғы зиялыларды анықтау бойыгша жаңа әдіснамалық нұсқауларға негізделіп, сенімді далалық және өмірбаяндық материалдарға талдау жүргізілген. Ол қазіргі заманғы бурят ауылдық қоғамында бұрыннан белгілі типологиямен сәйкес келмейтін жаңа форматтағы интеллигенцияның болуын анықтауға мүмкіндік берді. Зерттеу нәтижесінде осы әлеуметтік қабатқа бұрын енгізілмеген бірқатар адамдар енгізілді. Олар - стандартты жоғары, сондай-ақ арнайы буддистік білімі жоқ буддисттер. Олардың дүниетанымын қалыптастыру процесі білімді қарттардан қызығушылық танытқан жастарға дәстүрлердің арнайы ұрпақ арқылы ауысуы көрсетіледі. Бұл жағдай тарихтың дағдарыс кезеңдеріне тән, ал білімнің аудармасы ауызша түрде және ескі монғол жазуымен жазылған будда кітаптарында орын алады. Бұл кішігірім мемлекеттердің шекараласуы нәтижесінде қалыптасқан жеке психологиялық адамдар түрі. Адамдардың бүкіл Бурятия аумағына таралғаны анықталды. Бұл топқа ерлермен бірге әйелдер де енгені анықталды. Олардың міндеті - дәстүрлі мәдениеттің элементтерін, оның ішінде жаһандық әлемдегі этностардың тіршілік етуінің негізі ретінде дінді жандандыру. Этностардың мүдделеріне адамдардың осындай бейілділігін этно-ұлтшылдыққа жатқызуға болмайды, бірақ этнос пен оның тілі,мәдениетін сақтау және дамыту үшін алаңдаушылық туғызатын этнофилия деп санауға болады. Мақалада ауыл тұрғындарының жалпы санында олардың аз ғана бөлігі бар, алайда олар ауылдық қоғамның тұрақты дамуында, полиэтникалық ортадағы кішкентай адамдардың этникалық ерекшеліктерін сақтауда маңызды рөл атқарады деген қорытынды жасалынады.
\end{abstract} Кілт сөздер: ауыл қоғамы; бурят-буддисттер; зиялылар; ерекшелігі; дәстүрлі; жандану; тұрақты даму.

\section{Современная бурятская сельская интеллигенция}

\section{Жамбалова Сэсэгма Гэндэновна}

доктор исторических наук, доцент, ведущий научный сотрудник Института монголоведения, буддологии, тибетологии СО РАН. Российская Федерация, 670047, Улан-Удэ, ул. Сахьяновой, 6. E-mail: zhambalovas@yandex.ru 
Абстракт. В данной статье на основе принципиально новых методологических установок по идентификации современной интеллигенции проведен анализ достоверных полевых и биографических материалов. Он позволил обнаружить в современном бурятском сельском социуме наличие интеллигенции нового формата, не совпадающего с известной ранее типологией. В результате исследования в данную социальную прослойку введен круг людей, ранее не входивших в него. Это буддисты-миряне, не имеющие стандартного высшего образования, а также специального буддийского. Показан процесс формирования их мировоззрения путем особой межпоколенной трансляции традиций от знающих стариков заинтересованным молодым людям. Такая ситуация характерна для кризисных периодов истории, а трансляция знаний происходит как в изустной форме, так и на буддийских книгах старомонгольской письменности. Это люди с особым психологическим типом личности, сложившимся в результате малых пограничных состояний. Выявлено, что такой тип людей распространен по всей Бурятии. Показано, что в этот круг наравне с мужчинами входят женщины. Их задача - возрождение элементов традиционной культуры, в том числе религиозности как основы выживания этноса в глобальном мире. Такую приверженность людей интересам своего этноса нельзя отнести к этнонационализму, а следует рассматривать как этнофилию, которая предполагает заботу о сохранении и развитии этноса, его языка и культуры. В статье сделан вывод, что в общей массе сельского населения их немного, однако, они играют важную роль в устойчивом развитии сельского социума, в сохранении этнической специфики малого народа в полиэтничном окружении.

Ключевые слова: сельский социум; буряты-буддисты; интеллигенция; специфика; традиционализм; возрождение; устойчивое развитие.

\section{әОЖ/ УДК 394/ 395 (571.54)}

\section{Современная бурятская сельская интеллигенция ${ }^{1}$}

\section{С.Г. Жамбалова}

В данной статье на базе достоверных полевых и биографических материалов с использованием современных методологических установок сделана попытка рассмотреть специфичность интеллигентского слоя в современном бурятском сельском социуме, отличающемся определенным традиционализмом. Глубинный подход к идентификации интеллигенции позволяет значительно расширить этот пласт народа за счет отнесения к данной категории особых представителей этноса, часто не имеющих достаточно высокого уровня образованности в общепринятом понимании. За рамками исследования сознательно оставлен довольно широкий круг выдающихся представителей современной бурятской интеллигенции, не входящих по определенным признакам в данную дефиницию.

В настоящее время в широком обиходе к представителям интеллигенции данного этноса конца XIX - начала XX в. обычно относят выдающихся бурятских деятелей, которые в большинстве своем европейски образованы, а также высокообразованных буддийских священнослужителей, некоторых сельских учителей и представителей степной администрации. В результате идеологической ревизии в советское время среда интеллигенции, с одной стороны, значительно сужена за счет исключения из ее рядов большинства вышеперечисленных категорий людей. С другой, она значительно расширена за счет формирования так называемой советской национальной интеллигенции, прослойки людей, профессионально занятых умственным трудом. В основном это работники так называемой бюджетной сферы - образования, здравоохранения, науки и т.д.

1 Работа выполнена в рамках государственного задания Федерального государственного бюджетного учреждения науки «Институт монголоведения, буддологии и тибетологии Сибирского отделения Российской академии наук (ИМБТ СО РАН)» по проекту XII.191.1.1. "Трансграничье России, Монголии и Китая: история, культура, современное общество», номер госрегистрации № АААА-А17-117021310269-9. 
В современной науке существует объективная невысокая оценка данного слоя населения. Это довольно распространенное в постсоветское время суждение нашло отражение в следующей цитате: «В функциональной системе, именовавшейся реальным социализмом, интеллигенция утратила свою идентичность; насмешкой судьбы можно считать сохранение ее имени для обозначения определенной рубрики в таблице социально-профрессиональных позиций. Наличие высшего образования или принадлежности к группе "преимущественно умственного труда" в статистических отчетах не составляет основы какого-либо функционального или морального единства, как не дает принадлежности к элите общества» (Левада 1989: 130).

В данной статье используется социальное значение слова «интеллигенция», которое подразумевает общественную группу людей, обладающих критическим способом мышления, высокой степенью рефлексии, способностью к систематизации знаний и опыта. Данная дефиниция получает широкое развитие в постсоветское время. Ю.А. Левада пишет: «Это не только группа образованных людей, но некая общность, видящая смысл своего существования в том, чтобы нести плоды образованности (культуры, просвещения, политического сознания и пр.) в народ и уподобляющая эту задачу священной (по меньшей мере, культурно-исторической миссии)...» (Левада 1989: 128).

Методологической основой статьи является понятие интеллигентности, как психологического свойства человека, получившее наибольшее развитие в телевизионной авторской программе Ю.М. Лотмана. Еще в конце 1980-х гг. выдающийся литературовед, культуролог, основоположник отечественной школы семиотики Ю.М. Лотман записал для телевидения цикл из 22 телевизионных передач «Беседы о русской культуре». Он восстановлен в 1998 г. и неоднократно включается в сетку вещания (Лотман 1998). К 90-летию всемирно известного ученого канал «Культура» показал в феврале - марте 2012 г. несколько основных программ цикла в рамках проекта Academia. К сожалению, в одноименной книге ученого нет подобных высказываний, также нет их в специальной статье, посвященной анализу интеллигентского дискурса, поэтому во всех случаях предпринята ссылка на анонс передачи.

Самый поверхностный взгляд на историю роли интеллигенции в становлении бурятского сельского социума с 1930-х до 2011 г. показывает наличие на диахроническом срезе двух диаметрально противоположных векторов, обусловленных появлением новых политических тенденций и совпавших с началом строительства новых государств - СССР и РФ. В первом случае поставленная перед советской сельской интеллигенцией, где немало коммунистов, задача носила характер государственного заказа. Ее целью было преодоление религиозности населения и отход от традиционной жизни. Движущей силой второго, легализовавшегося в постсоветский период, был народ, а ее лидеров можно смело отнести к ярым противникам коммунистической идеологии. Их задача - возрождение элементов традиционной культуры, в том числе религиозности как основы выживания этноса в глобальном мире. Такую приверженность людей интересам своего этноса нельзя отнести к этнонационализму, а следует рассматривать как этнофилию, которая предполагает заботу о сохранении и развитии этноса, его языка и культуры.

Г.Е. Марков объективно отмечает, что в дореволюционной России общее развитие шло в сторону складывания ряда общих черт в жизнедеятельности народов России (Марков 1985: 256). Однако наибольшее ускорение этот процесс получил в первые десятилетия советской власти, которые отличает активная работа по преодолению проявлений этничности, так называемая 
«борьба с пережитками». Происходил динамичный процесс ликвидации религии, традиций, обрядов и обычаев народов страны, который приводил в конечном итоге к созданию стереотипов советской повседневности за счет выравнивания образа жизни всего населения. В этом довольно длительном процессе, занявшем не менее четверти века, немалую роль сыграли специалисты сельского хозяйства, сельские учителя, медицинские работники.

В СССР среди рабочих и передовой части общества перспективной моделью образа жизни, критерием его качества становятся социалистические идеалы, модель социалистического общества с соответствующим социалистическим образом жизни (Марков 1985: 250). Таким образом, происходила определенная унификация повседневности за счет стирания этнической специфики, постепенно затронувшая сельское население. Благодаря конкретным социальным гарантиям - бесплатное образование, бесплатная медицина, бесплатное жилье и пр. - создавался советский образ жизни. Прав Г.Е. Марков, когда замечает: «Одновременно с сложением советского народа как новой исторической надэтнической общности сложился и общесоветский образ жизни как тип социалистической жизнедеятельности» (Марков 1985: 259). Такая государственная политика дала бесспорные позитивные результаты, заложила основу дальнейшего развития РФ. Однако, по мнению определенных групп населения, она имела ряд негативных черт.

Полевая работа, беседы с людьми, в том числе с представителями русских старообрядцев и карымов, показывают, что в СССР многие буряты, как и представители других этносов, субэтносов, этнографических групп региона, стеснялись знания родного языка, диалектного говора, национального имени, наличия акцента в русском языке и других внешних проявлений собственной этничности. Поэтому определенная часть населения прилагала большие усилия для их преодоления. В постсоветское время наблюдается более позитивная оценка собственной этничности.

Сам распад СССР и начало истории РФ совпадает с центробежными этническими тенденциями конца $\mathrm{XX}$ в. Во всем мире, возможно, за исключением двух-трех стран Западной Европы и США после стремительного модернистского движения к индустриализации наблюдается неожиданный всплеск традиционализма, так называемый этнический парадокс или этнический ренессанс. Не явилась исключением и Россия. В бурятском сельском социуме это движение возглавляет круг людей, который согласно теории Ю.М. Лотмана, можно отнести к категории постсоветской интеллигенции, апологетов возрождения бурятской традиционной культуры. Так, в одной из передач, он говорит: «Отдельные люди аккумулируют национальную культуру. Они выступают, как лаборатории или библиотеки. И гибель одного такого человека - настоящая национальная трагедия» (Лотман 1998).

Буряты за годы советской власти утратили основополагающие составляющие традиционной культуры кочевников-скотоводов сухих степей, его хозяйственно-культурный тип с тремя основными подсистемами культуры жизнеобеспечения - жилище и поселения, одежда, пища, многие элементы духовной культуры и в некоторой степени родной язык. Однако в каждом поколении появляются отдельные люди, подверженные традиционализму. В зависимости от личных возможностей на различных уровнях (семья, село, район, республика, диаспоры) они способствуют возрождению элементов традиционной культуры, создают благоприятную почву для их количественного и качественного роста.

Однако не все представители бурятского этноса подвержены традиционализму. Для создания объективной картины, в статье, посвященной интеллигентам- 
традиционалистам, необходимо упомянуть о так называемых аутсайдерах, сознательно порывающих с традиционным социумом. Они известны с самого начала этнокультурного взаимодействия бурят и русских (Жамбалова 2000: 74-76). Видимо, в любом обществе имеются индивидуумы с редуцированным этническим самосознанием, они составляют пограничные слои, легко вовлекаемые в процесс естественной ассимиляции доминирующим народом. Думается, что в настоящее время отход людей от идеалов традиционного социума происходит по известным объективным причинам намного интенсивней, чем в дореволюционное время (Жамбалова 2008: 233-234). Однако явно выраженной идеологии здесь пока не наблюдается, все проходит в рамках естественной ассимиляции.

Процесс возрождения этнических традиций в российском обществе, бесспорно, получает большее развитие среди национальных меньшинств страны. При декларированном равноправии всех народов/субъектов в каждом полиэтничном государстве в той или иной степени существует проблема малых народов. Нет сомнения, что для них особо остро стоит проблема выживания: велика опасность ассимиляции малочисленного образования в полиэтничном окружении, открытых границах и глобализации (Жамбалова 2010а: 233-234).

Буряты как малый народ крупного полиэтничного государства должен на протяжении довольно длительного времени заботиться о сохранении этничности. Известно, что этническая идентичность - нечто, проявляющееся во взаимодействии. В условиях всеобщей моноэтничности проблемы «мы - они», лежащей в основе этнической самоидентификации, просто не было бы. Этничность может расти или ослабевать в ответ на внешние условия. Считается, что в качестве источника этнической идентичности выступают притеснения и гонения, переживаемые этнической группой (Лурье 1997: 187). Советский этап развития характерен стремлением ликвидировать сам вопрос сохранения этничности, однако наступление новой идеологии обнажило существующую проблему и потребовало поисков путей ее решения. Это вовсе не говорит о том, что буряты или другие народы России подвергаются притеснению в своей стране. Наоборот, ни для кого не секрет, что именно в условиях Российской империи, затем СССР и РФ буряты как этнос получают все большее развитие. Тем не менее, проблема сохранения этноса существует (Жамбалова 2010а: 238).

В ее решении велика роль современной интеллигенции, людей, сформировавшихся в сельской среде традиционалистов. Бурятское сельское общество в определенные, в основном сакральные, моменты адекватно традиционному социуму, так же бывало и в советскую пору, чему есть множество свидетельств. Правда, тогда из-за умышленных «чисток» культуры данное превращение носило тайный характер и затрагивало узкий круг людей. Вообще России характерно сочетание традиционной и современной культур.

В возрождении бурятской традиционной культуры велика роль личности республиканского значения - председателя Всебурятской ассоциации развития культуры (ВАРК) Б.Д. Баяртуева (1950-2006), выходца из села. Безусловно, это интеллигент одновременно и в общепринятом, и в современном понимании слова. Свидетельство тому объективная оценка всех граней его деятельности известным бурятским ученым Ш.Б. Чимитдоржиевым, который пишет: «Почти 15 лет возглавлял Б.Д. Баяртуев Всебурятскую организацию и внес крупный вклад в возрождение традиционной культуры бурят-монгольского народа, его обычаев, обрядов и праздников. Он являлся автором крупных всебурятских национальных проектов, инициатором и организатором многих народных 
праздников, фольклорно-художественных смотров и фестивалей. Например, он был организатором такого крупного мероприятия бурят и других монгольских народов, как 1000-летие эпоса “Гэсэр”. Бата Баяртуев был народным трибуном, прекрасным оратором. Любили его слушать, слушать его глубоко эмоциональные, весьма содержательные выступления, посвященные проблемам возрождения и закрепления бурят-монгольских традиций и обычаев, языка и письменности. Он был крупным ученым, ученым-аналитиком. Он сыграл большую роль в изучении истории развития бурят-монгольской литературы, фрольклорных традиций бурятского народа» (Чимитдоржиев 2008: 5).

Реализация гражданской позиции традиционалиста Б.Д. Баяртуева стала возможной, начиная с перестроечного времени. Активная общественная деятельность началась с первых постсоветских лет в рамках созданной не без его деятельного участия Всебурятской ассоциации развития культуры (ВАРК). На Всебурятском съезде (1991), где была создана эта общественная организация, он избран вице-президентом, а затем через годы президентом. Эту работу он успешно совмещал с серьезной научной в Институте монголоведения, буддологии и тибетологии СО РАН (ИМБТ СО РАН), где в 2002 г. защитил докторскую диссертацию по теме «Фольклорные истоки литературы бурят-монголов», и преподавательской в Бурятском госуниверситете, где он был одним из организаторов и первым завкафедрой бурятской литературы. Ранняя смерть Б.Д. Баяртуева была воспринята многими людьми как национальная трагедия. Об этом свидетельствует беспрецедентно большой список некрологов, помещенных в республиканских газетах.

Б.Д. Баяртуев в некоторые периоды истории республики, особенно в начале 2000-х гг., был неугоден представителям власти РБ, о чем было известно общественности. Однако он не сдал идеологических воззрений и принципиальных позиций, что свидетельствует о мужестве. И это не случайность. В 17-м выпуске «Беседы о русской культуре» Ю.М. Лотман дает определение понятия «интеллигентность», которое включает в себя не только доброту и терпимость, но стойкость, твердость и героизм (Лотман 1998).

О том, что Б.Д. Баяртуев сполна обладал этими необходимыми качествами, свидетельствуют факты жизни, которая, к счастью, была правильно и высоко оценена его современниками, правда, уже после ухода. На обложке сборника материалов конференции «Баяртуевские чтения - 1» совершенно верно написано: «Б.Д. Баяртуев до конца своей жизни оставался верным своему слову, делу, идеалу. Человеком долга и чести, подвижником, патриотом бурятского народа, его могучей возрожденческой фигурой. Он был просто Баяртуевым - образцом высокого служения и подражания. Другим он не мог быть, иначе не мог жить...» (Баяртуевские 2008).

Ю.М. Лотман убеждает, что культура - понятие духовное, а интеллигентность - психологическое свойство человека. Он говорит о среде, из которой выходят люди «интеллигентского сознания», о том, как в России XVIII-XIX вв. складывался тип «людей искусства, людей книги и людей мысли». Конечно, он говорит о русском дореволюционном обществе, о роли дворянства России в формировании «интеллигентского сознания», что не может быть применимо к современным реалиям. Тем не менее, имеет значение сама мысль о том, как важна среда, в которой происходит становление человека (Лотман 1998).

Б.Д. Баяртуев родился и вырос в Кижингинском районе РБ в многодетной семье учителей Б.С. Мункиной и Д.Г. Баяртуева. Отец в течение 26 лет был 
директором Кижингинской средней школы. Дед по отцовской линии занимался организацией сельскохозяйственного производства, дед по матери - работал председателем колхоза и председателем райпотребсоюза. Его родным дядей по материнской линии был выдающийся религиозный деятель и ученый Бидиядара Дандарон (Чимитдоржиев 2008: 6).

Другой яркий представитель современной бурятской интеллигенции известный поэт, ученый и человек «искусства, книги и мысли», Б.С. Дугаров записал в дневнике 10 ноября 1982 г.: «В обед пошел к Б. Баяртуеву... Много говорили о Дандароне. У него есть последователи в Ленинграде, Прибалтике, Бурятии. Биография у Дандарона необычная, кармическая. Ему было суждено остаться единственной, уцелевшей после сталинских репрессий живой нитью, связующей с сакральной традицией буддийского прошлого. Он был как бельмо на глазу у сегодняшних идеологов. Нес нелегкую ношу как последний верблюд, отставший от своего каравана...» (Дугаров 2011: 367). Далее он характеризует Б.Д. Дандарона как выдающегося ученого-тибетолога, вспоминает случайную встречу и упоминает о судебном процессе над ним. Нет сомнения, исключительная жизнь и судьба Б.Д. Дандарона, взращенная особой средой кижингинской долины, оказала большое влияние на становление личности Б.Д. Баяртуева. Будучи родственником, Баяртуев хорошо знал его биографию, круг его единомышленников, ездил к нему в тюрьму в Выдрино. Из-за родственной связи с опальным дядей он подвергался остракизму во время учебы в БГПИ им. Д. Банзарова (Дугаров 2011: 368).

Как известно, в ответ на сложные политические перипетии второго десятилетия XX в., появилось стремление создать в отдельно взятом Кижингинском хошуне буддийское теократическое государственное образование, которое получило в дальнейшем название теократического (балагатского) движения в Хоринском ведомстве (1919-1926) под руководством ламы-созерцателя Лубсан-Сандан Цыденова. В результате постоянного глубокого постижения буддийской философии и практики Л.-С. Цыденов уходит из Кижингинского дацана, возрождает принципы непосредственного ведения учителем ученика, начинает распространять нетрадиционную форму буддизма в Бурятии - внедацанскую. Он считает, что в XX в. потребуются новые правила устройства сангхи. Новый взгляд Цыденова на дальнейшее устойчивое развитие буддизма определил духовный путь многим поколениям не только в Бурятии, но и за ее пределами (Дарибазарон 2008: 4, 3, 55).

Буддийская традиция считается живой, если она передается от учителя к ученику. У Л.-С. Цыденова было много учеников, но самым близким, «коренным» являлся Агван-Доржи Бадмаев, который умер в тюрьме от тифа в 1920 г. В 1921 г. на освящении нового дацана теократов, Шелотского, официально был провозглашен наследник престола - семилетний Бидиядара Дандарон (1914-1974). Он родился в семье бурятского религиозного поэта и йогина Доржи Бадмаева. Его духовный учитель Л.-С. Цыденов стал учителем его сына, передав свои полномочия «царя учения». Б.Д. Дандарон стал Учителем, вошел в историю буддизма России как наставник тантрийского учения (Дарибазарон 2008: 102).

Неизвестно, был ли Б.Д. Баяртуев непосредственным учеником Б.Д. Дандарона. Не подлежит сомнению, он находился в ближайшем его окружении и неплохо ориентировался в постулатах учения. Об этом свидетельствует Э.Ч. Дарибазарон (Дарибазарон 2008: 57). Для данной статьи интересно то, как повлияла религиозная духовная среда на формирование личности Б.Д. Баяртуе- 
ва. Высокая религиозность в то время могла взрасти на благодатной почве глубокой традиционности быта и культуры. Поэтому, несомненно, только одно - Б.Д. Баяртуев впитал все лучшее, что было в традициях его семьи, малой родины, Бурятии и России. Это он пытался передать народу и сохранить в поколениях. Это были не религиозные постулаты, распространение которых удел священнослужителей, а культурное наследие народа во всех его проявлениях.

Выдающиеся личности в ссрере воспроизводства этнических констант в свое время определены мной как стражи, хранители традиционного социума (Жамбалова 2008), они являются авангардом современной бурятской сельской интеллигенции. Рассматривая вопрос, каким образам этническим константам удается на протяжении столетий передаваться из поколения в поколение, исследователи приходят к следующему: «Внутри этноса ... должны быть люди, модус отношений которых к традиции является иным, чем у основной массы... Те, кто основные доминанты культурной традиции выбрал для себя сам» (Лурье 1997: 306). Тип сознания подобных людей является личностным в отличие от традиционного.

Увеличение в обществе носителей личностного сознания связано с кризисным состоянием социума. Оказывается, сохранение целостности традиционного сознания не является делом коллектива, напротив, поддержание целостности традиций, этнической картины мира - задача отдельных людей с личностным сознанием, которых, в полном соответствии с теорией Ю.М. Лотмана, определяем как современных бурятских сельских интеллигентов. В действительности, личностным сознанием обладает незначительное число людей. Эти люди могут сознательно выйти из своего традиционного общества, могут сознательно в нем оставаться: или для того, чтобы его изменить, или для того, чтобы его сохранить. Особого внимания заслуживают люди с личностным сознанием, осмыслено остающиеся в своем традиционном обществе для того, чтобы сохранить его стабильность. В процессе формирования личностного сознания происходит изменение всей психики через серию малых пограничных ситуаций, при которых происходит незначительный толчок - встреча, впечатление, случайно высказанная мысль - и человек приходит к новому уровню понимания реальности (Лурье 1997: 306, 307, 310, 319).

Данное теоретическое положение подтверждает биография Норжимы Цыбжитовны Балбаровой, бурятки из рода галзут. Она родилась в 1925 г. в местности Байсын Убэр Хоринского р-на РБ. У ее отца было крепкое хозяйство: свыше 100 голов коров, 40 лошадей, 150 овец. Он достраивал большой дом на 10 окон, когда его зачислили в кулаки. В 1932 г. все имущество конфисковали, а в доме, который до сих пор называют домом Балбара, разместили школу. Отца посадили в тюрьму, где он и умер. А Норжиму с матерью на два года отправили на тюремные работы. После освобождения они поселились в с. Баянгол Хоринского р-на РБ. Раскулачивание отца Н.Ц. Балбарова объясняет близким родством отца с тремя ламами Анинского дацана. Это были его сын, брат и дядя. В то время ламы не обзаводились семьями и имуществом - их содержали родственники. По мнению информанта, именно по этой причине отец разводил много скота часть молока и мяса уходили в дацан (Жамбалова 2008: 231).

Казалось бы, типичная история детства и отрочества человека, родившегося в СССР в 1920-е г. в зажиточной семье. Однако она имеет продолжение, которое значительно углубляет степень обоснованности научных положений данной статьи. Н.Ц. Балбарова после подобных жизненных катаклизмов, в отличие от многих, сохранивших страх перед властью, решила способствовать 
возрождению устоев семьи своего отца. После выхода на пенсию Н.Ц. Балбарова проживает с мужем в с. Хоринск, районном центре, полиэтничном крупном селе. С сорока лет (1964г.) она читает буддийские молитвы (маани): «Своим умом дошла: ни папы, ни мамы, ни лам не было. Брат мой лама умер в холодных краях. Через людей передавал, что под землей в землянке живет по колено в воде, все тело опухло. В Кижинге был Борхеев лама, который чудом спасся от расстрела. Этот дед много ходил по деревням, читал молитвы, проводил обряды. Мы познакомились и подружились. Я стала посещать места, где читали молитвы, участвовать в трехдневных молитвах с соблюдением строгих постов. До сих пор хожу молиться. Приняла обеты (мацагай санар һасил абаб)» (Жамбалова 2008: 231-232).

В 2008 г., когда записывался приведенный полевой материал, Н.Ц. Балбарова в свои 84 г. по бурятскому исчислению возраста, все свободное от молитв и домашних дел время посвящала пошиву технологически сложных ритуальных украшений интерьера дацанов (жодбон, жалсан, бадан, лаври), которые шьются из дорогих тканей. Готовые изделия она преподнесла многим возрождающимся дацанам. Люди, знающие о ее благотворительной деятельности по возрождению дацанов, тоже стараются внести свою лепту - приносят китайский шелк, парчу, тесьму (Жамбалова 2008: 231-232).

По всей видимости, такой деятельностью занимается немало верующих буряток. Кстати, моя мама, Дугарма Рабдановна Очирова, 1928 г.р., уроженка Селенгинского р-на, из рода улахан олзон, в 1990-е гг. преподнесла одному из городских дацанов сшитые ею изделия буддийского интерьера. Известно, что в 1982 г. в Хоринске жила Гомбоева Сэндэма Гомбоевна, родом из Кижинги, «уникальный человек, из тех немногих, кто сохранил традицию старой бурятской культуры». 17 июля 1982 г. она показала Б.С. Дугарову изделия, сшитые ею. Вот что зафиксировал он тогда: «... красочные буддийские жалсаны и другие культовые вещи. Все это бережно хранится у нее, часть их взяли ламы и верующие миряне. Ее работы высоко ценятся. Я тоже не смог скрыть своего изумления» (Дугаров 2011: 203-204). Имеющиеся материалы дают основание считать, что традиция практически не прерывалась, а учителем Н.Ц. Балбаровой, возможно, была С.Г. Гомбоева. По крайней мере, она сохранила традицию женщин-мирян и по эстафрете передала следующему поколению.

Два сюжета о похожих женщинах из одного крупного районного центра с превалирующим русским населением, с большим партийным и иными ресурсами по подавлению инакомыслящих, позволяют проследить довольно распространенное в середине XX в. явление в традиционном сельском социуме. Это особая инновационного характера межпоколенная трансляция традиционных знаний, обусловленная кризисным состоянием общества. Происходит осознанная, намеренная передача багажа народного традиционного опыта, в том числе религиозного характера, не в привычных пределах семьи и поселения, а от знающих стариков заинтересованным в этих знаниях более молодым людям. В традиционном обществе почетный старик - это социальная роль, хранитель жизненного опыта, народных знаний и обычаев, как бы предок (Сагалаев, Октябрьская 1990: 78-79). Отставные священнослужители, в том числе буддийские монахи, ламы, вернувшиеся из мест заключения и ссылок, передавали свои знания в тайных кружках, которые были во многих местах РБ. Ученики находили Учителей, которые в данном случае были выходцами из Кижинги. 
Географию такой традиции значительно расширяют другие достоверные материалы из дневника 1982 г. Б.С. Дугарова. Здесь он выступает в роли неофрита, жаждущего знаний новообращенного. Зафиксирована его работа со знатоками буддийских текстов на старомонгольском и тибетском языках, мужчинами и женщинами, в Бичурском, Селенгинском, Тункинском, Хоринском p-нах РБ. Упоминаются знающие люди из Окинского р-на РБ, Агинского р-на Забайкальского края. Понятно, что многочисленные факты его поиска и бесед со знающими людьми связаны с научной профессиональной деятельностью литературоведа-ориенталиста и носят характер полевых исследований. В то же время просматривается глубоко человеческая заинтересованность в традиционной культуре своего народа, выпестованная в интеллигентной, имеющей глубокие корни семье. Вообще этот дневник - энциклопедия жизни бурятского интеллигентного человека того времени.

В качестве доказательства приведем некоторые записи. С 8 по 14 марта 1982 г. в селе Харбяты Тункинского р-на РБ Б.С. Дугаров со своим дядей читает «Намтар» Миларайбы на монгольском языке. Учителем молодого ученоговостоковеда является пожилой сельский житель, не имеющий высшего образования. Казалось бы, фиксируется обычная исследовательская работа по сбору научных материалов, в то же время - это достоверные свидетельства еще одной грани интеллигентского в сельском социуме. Она нашла отражение в записях нескольких дней, наиболее информативные из них последовательно приведены здесь. 8 марта записано: «С Дэбшэн-хуряахой читаем "Намтар" Миларайбы. Он сразу переводит на тункинско-бурятский говор». 9 марта: «Прочитал 36 стр. «Намтара» (до 73 стр.). Очень интересен рассказ Дэбшэнхуряаха о смерти Дарма-Доди, сына Марбы. Три категории запрета. Тетя Санжид днем читала “Доржо Жодбо”, по-монгольски “Очироор огтологчи” (“Алмазом отсекающий"), настольная книга у пожилых мирян-буддистов. Эта “Алмазная" сутра содержит номлол-учение о пустоте-шуньяте (хогосон шанар) и о путях избавления от пут сансары. Через накопление добродетелей (буян хуряах) и обретение лучшего перерождения (сайн турлоо олох) - достижение буддийского эдема Диважин». 10 марта: «С Дэбшэн-хуряахой весь день с небольшими перерывами читали “Намтар” Миларайбы... Тетя Санжид читает свой старомонгольский текст» (Дугаров 2011: 71). 12 марта: «Ходил к Цыденову Биликто-таабай. Он дал "Намтар" Дзонхавы. Его жена - бабушка Сэрэмжит еще в пятилетнем возрасте была в дацане с братьями. Знала немного по-тибетски» (Дугаров 2011: 70, 71, 73).

Эти скупые, на первый взгляд, строки значительно расширяют список интеллигентных людей села за счет включения новых лиц, в том числе женщин. Этот на самом деле небольшой круг подобных личностей был распространен по всей Бурятии. Подтверждение находится также в дневнике Б.С. Дугарова, который 16 июля записал о своей поездке в Хоринск: «Целый день - с 9 утра до 9 вечера провел у Сэндэмы Гомбоевны, знатока старины, монгольской и буддийской литературы. Она уникальный человек, из тех немногих, кто сохранил традиции старой бурятской культуры» (Дугаров 2011: 203). О С.Г. Гомбоевой, о которой уже упоминалось выше, он пишет 29 октября: «Заходил к бабушке Сэндэме. В здравии, сидела на кровати, читала небольшой ксилографф (старомонгольский)... У нее есть "Намтар" Миларайбы, он хранится в шкафу, под танка с изображением Ямандаги, в числе других книг. Опять пересказала фрагменты из “Намтара” Миларайбы. Советует мне познакомиться с Бадмае- 
вым Жамьяном Бадмаевичем, зам. редактора газеты "Удинская новь". У него тоже хранятся старомонгольские книги. Сидели, беседуя, пока не стемнело и не пришла соседка» (Дугаров 2011: 348-349).

Имеются источники, позволяющие проследить и тем самым доказать неразрывность существующей традиции, которая, по всей видимости, возникла в 1930-е гг. как ответ на вызовы воинствующего атеизма, активизировалась в послевоенное, с приходом из ссылок некоторых уцелевших священников и появлением определенных уступок со стороны государства в области религиозной политики, а затем в постсоветское время. В 1998 г. записано, что в Еравнинском р-не РБ с 1947 г. люди почувствовали конец атеистического прессинга, стали тайно собираться в удаленном от центра с. Улзыта и ночами читать буддийские молитвы (сангарил). Людей, читающих буддийские книги на старомонгольском языке, по всей видимости, было немало, жили они в разных районах республики. Например, в с. Эгита в 1998 г. проживала Б.Б. Лодоева, 1914 г.р. С 70 лет она читает буддийские книги, так как раньше было некогда. Старомонгольскую грамоту знает с детства - обучил дядя, лама Эгитуйского дацана, не вернувшийся из далекой ссылки (Жамбалова 2000: 344). Также зафиксировано, что подобное происходило в с. Ацагат Заиграевского р-на РБ (Жамбалова 2010б: 201).

Не случайно основная деятельность современных сельских интеллигентов связана, в первую очередь, с возрождением религии, в данном случае, буддизма. Е.С. Элбакян утверждает, что именно интеллигенция распространяет культурные ценности, в том числе и религиозные, среди всех социальных слоев и передает их в различных фрормах будущим поколениям. Также известна позитивная компенсаторная функция религиозных ценностей в периоды общественных кризисов и социальных катастроф (Элбакян). Видимо, определенная возможность реализации мировоззренческих установок помогла многим противникам коммунистической идеологии пережить тяжелые времена разрушения фундаментальных устоев жизни - церкви и заветов предков.

Анализ приведенных источников на основе принципиально новых методологических установок по идентификации современной интеллигенции позволяет прийти к выводам, которые могут иметь значение для дальнейших исторических исследований в области бурятоведения. Исследование эмпирических материалов позволило обнаружить в современном бурятском сельском социуме наличие интеллигенции нового формата, не совпадающего с известной ранее типологией. В результате изыскания в данную социальную прослойку вводится круг людей, ранее не входивших в него. Это буддисты-миряне, не имеющие стандартного высшего образования, а также специального буддийского. Процесс формирования их мировоззрения происходит путем особой инновационного характера межпоколенной трансляции традиций от знающих стариков заинтересованным молодым людям, состоявшейся часто за пределами семьи и поселения. Такая ситуация характерна для кризисных периодов истории, а трансляция знаний происходит как в изустной форме, так и на буддийских книгах старомонгольской письменности. Это люди с особым психологическим типом личности, сложившимся в результате малых пограничных состояний. Такой тип людей распространен по всей Бурятии. В этот круг наравне с мужчинами входят женщины. Их задача - возрождение элементов традиционной культуры, в том числе религиозности как основы выживания этноса в глобальном мире. Такую приверженность людей интересам своего этноса нельзя отнести к этнонационализму, а следует рассматривать как этнофилию, которая 
предполагает заботу о сохранении и развитии этноса, его языка и культуры. В общей массе сельского населения их немного, однако, они играют важную роль в устойчивом развитии сельского социума, в сохранении этнической специфики малого народа в полиэтничном окружении.

\section{Әдебиет тізімі / Список литературы}

1. Мир бурятских традиций в контексте истории и современности: материалы международных научных чтений (г. Улан-Удэ, 2-3 октября 2008 г.). - Улан-Удэ: Изд-во Бурят. гос. ун-та, 2008. - 240 с.

2. Дарибазарон Э.Ч. Теократическое движение в Хоринском ведомстве Бурятии (1919-1926 гг.). - Улан-Удэ: Изд-во Бурят. гос. ун-та, 2008. - 180 с.

3. Дугаров Б.С. Сутра мгновений. - Улан-Удэ: Изд-во ОАО «Республиканская типография», 2011. $-440 \mathrm{c}$.

4. Жамбалова С.Г. Профанный и сакральный миры ольхонских бурят (XIX-XX вв.). - Новосибирск: Наука, 2000. - 400 с.

5. Жамбалова С.Г. Страж и аутсайдер: о людях с личностным сознанием в традиционном социуме // Этнокультурное и фольклорное наследие монгольских народов в контексте истории и современности. - Улан-Удэ: Изд-во БНЦ СО РАН, 2008. - С. 229-234.

6. Жамбалова С.Г. Модернизация и традиционализм: проблемы специфики этнических процессов народов Бурятии в постсоветский период // Сибирь в изменяющемся мире. История и современность: мат-лы всерос. науч.-теорет. конф. - Иркутск: Изд-во Вост.-Сиб.гос. акад. образов, 2010. - С. 233-239.

7. Жамбалова С.Г. Село Ацагат Бурятии - частичка обновляющейся России // Гуманитарные исследования Сибири в контексте обновления итсориографических практик: материалы Всероссийской научно-практической конференции и научно-практического семинара. - Братск: БрГУ, 2010. - С. 195-203.

8. Левада Ю.А. Интеллигенция // 50 / 50: Опыт словаря нового мышления. - М.: Прогресс, 1989. - С. $128-131$.

9. Лотман М.Ю. Беседы о русской культуре. - СПб.: «Искусство - СПб», 1994.

10. Лурье С.В. Историческая этнология: учеб. пособие для вузов. - М., 1997. - 448 с.

11. Марков Г.Е. Структура и исторические типы образа жизни // Этнографические исследования развития культуры. - М.: Наука,1985. - С. 244-261.

12. Сагалаев А.М., Октябрьская И.В. Традиционное мировоззрение тюрков Южной Сибири. Знак и ритуал. - Новосибирск: Наука. Сиб. отд-ние, 1990. - 209 с.

13. Чимитдоржиев Ш.Б. Бата Баяртуев - талантливый ученый, один из лидеров нации / Ш.Б. Чимитдоржиев // Баяртуевские чтения-1. Мир бурятских традиций в контексте истории и современности: материалы международных научных чтений (г. Улан-Удэ, 2-3 октября 2008 г.). - Улан-Удэ: Изд-во Бурят. гос. ун-та, 2008. - С. 5-6.

14. Элбакян Е.С. Интеллигенция в России: «мужество быть» или «самоутверждение вопреки»?: (философско-исторический анализ отношения интеллигенции 19 - начала 20 в. к религии). - М.: АТИСО, 2011. - 394 c.

\section{Reference}

Bajartuevskie chtenija 2008 - Bajartuevskie chtenija - 1. Mir burjatskih tradicij v kontekste istorii $i$ sovremennosti: materialy mezhdunarodnyh nauchnyh chtenij (g. Ulan-Udje, 2-3 oktjabrja 2008 g.) 2008, Izd-vo Burjat. gos. un-ta, UlanUdje, 240 s. (Bajartuevskie readings - 1. World of Buryat traditions in the context of history and modernity: materials of international scientific readings (UlanUde, October 2-3, 2008) 2008, Izd-vo Burjat. gos. un-ta, UlanUdje, 240 p). (in Rus).

Chimitdorzhiev 2008 - Chimitdorzhiev, ShB 2008, Bata Bajartuev - talantlivyj uchenyj, odin iz liderov nacii, Bajartuevskie chtenija - 1. Mir burjatskih tradicij v kontekste istorii $i$ sovremennosti: materialy mezhdunar. nauch. chtenij (g. Ulan-Udje, 2-3 oktjabrja 2008 g.), Izd-vo Burjat. gos. unta, Ulan-Udje, S. 5-6. (Chimitdorzhiev, ShB 2008, Bat Barthel - a talented scientist, one of the leaders of the nation, Bajartuevskie readings -1 . World of Buryat traditions in the context of histo$r y$ and modernity: materials of international scientific readings (Ulan-Ude, October 2-3, 2008) 2008, Izd-vo Burjat. gos. un-ta, UlanUdje, P. 5-6). (in Rus).

Daribazaron 2008 - Daribazaron, JeCh 2008, Teokraticheskoe dvizhenie $v$ Horinskom vedomstve Burjatii (1919-1926 gg.), Izd-vo Burjat. gos. un-ta, Ulan-Udje,180 s. (Daribazaron, JeCh 2008, $A$ Theocratic movement in horinskom office of Buryatia Republic (1919-1926), Burjat State un-ty Publishing house, Ulan-Udje,180 p). (in Rus). 
Dugarov 2011 - Dugarov, BS 2011, Sutra mgnovenij, Respublikanskaja tipografija, Ulan-Udje, $440 \mathrm{~s}$. (Dugarov, BS 2011, Sutra moments, Respublikanskaja tipografija, Ulan-Udje, 440 p). (in Rus).

Jelbakjan 2011 - Jelbakjan, ES 2011, Intelligencija v Rossii: «muzhestvo byt'» ili «samoutverzhdenie vopreki», Moscow, 394 p. (Jelbakjan, ES 2011, Intelligentsia in Russia: "courage to be» or «selfassertion contrary», Moscow, 394 p). (in Rus).

Levada 1989 - Levada, JuA 1989, Intelligencija, 50 / 50: Opyt slovarja novogo myshlenija, Progress, Moscow, P.128-131. (Levada, JuA 1989, Intelligentsia, 50 / 50: experience dictionary of new thinking, Progress, Moscow, P.128-131). (in Rus).

Lotman 1994 - Lotman, MJu 1994, Besedy o russkoj kul'ture, Moscow. (Lotman, MJu 1994, Talks about Russian culture, Moscow). (in Rus).

Lur'e 1997 - Lur'e, SV 1997, Istoricheskaja jetnologija: ucheb. posobie dlja vuzov, Moscow, 448 s. (Lur'e, SV 1997, Historical Ethnology: studies. the manual for high schools, Moscow, 448 p). (in Rus).

Markov 1985 - Markov, GE 1985, Struktura i istoricheskie tipy obraza zhizni, Jetnograficheskie issledovanija razvitija kul'tury, Nauka, Moscow, S. 244-261. (Markov, GE 1985, Structure and historical way of life, Ethnographic studies of the development of culture, Nauka, Moscow, S. 244-261). (in Rus).

Sagalaev 1990 - Sagalaev, AM, Oktjabr'skaja, IV 1990, Tradicionnoe mirovozzrenie tjurkov Juzhnoj Sibiri. Znak i ritual, Nauka Sib. otd-nie, Novosibirsk, 209 s. (Sagalaev, AM, Oktjabr'skaja, IV 1990, The Traditional world Outlook of Turks in South Siberia. Sign and ritual, Nauka Sib. otd-nie, Novosibirsk, 209 p). (in Rus).

Zhambalova 2000 - Zhambalova, SG 2000, Profannyj i sakral'nyj miry ol'honskih burjat (XIX-XX vv.), Nauka, Novosibirsk, 400 s. (Zhambalova, SG 2000, Profane and sacred worlds of Olkhon Buryats (XIX - XX centuries), Nauka, Novosibirsk, 400 p). (in Rus).

Zhambalova 2008 - Zhambalova, SG 2008, Strazh i autsajder: o ljudjah s lichnostnym soznaniem v tradicionnom sociume, Jetnokul'turnoe $i$ fol'klornoe nasledie mongol'skih narodov $v$ kontekste istorii $i$ sovremennosti, Izd-vo BNC SO RAN, Ulan-Udje, S. 229-234. (Zhambalova, SG 2008, Guardian and outsider: about people with personal consciousness in the traditional society, Ethnocultural and folklore heritage of the Mongolian peoples in the context of history and modernity, Izd-vo BNC SO RAN, Ulan-Udje, S. 229-234). (in Rus).

Zhambalova 2010 (1) - Zhambalova, SG 2010, Modernizacija i tradicionalizm: problemy specifiki jetnicheskih processov narodov Burjatii $v$ postsovetskij period, Sibir' $v$ izmenjajuwemsja mire. Istorija i sovremennost': materialy vseros. nauch.-teoret. konf., Izd-vo Vost.-Sib. gos. akad. obraz, Irkutsk, S. 233-239. (Zhambalova, SG 2010, Modernization and traditionalism: problems of specificity of ethnic processes of the peoples of Buryatia in the post-Soviet period, Siberia in the changing world. History and modernity: Mat-ly vseros. scientific.- theoret. Con, Izd-vo Vost.-Sib. gos. akad. obraz, Irkutsk, P. 233-239). (in Rus).

Zhambalova 2010 (2) - Zhambalova, SG 2010, Selo Acagat Burjatii - chastichka obnovljajuwejsja Rossii, Gumanitarnye issledovanija Sibiri v kontekste obnovlenija itsoriograficheskih praktik: materialy Vserossijskoj nauschno-prakticheskoj konferencii i nauchno-prakticheskogo seminara, BrGU, Bratsk, S. 195-203. (Zhambalova, SG 2010, Village Atsagat of Buryatia - a part of the renewed Russia, Humanitarian researches of Siberia in the context of updating itsoriographic practices: materials of All-Russian scientific-practical conference and scientific-practical seminar, BrGU, Bratsk, P. 195-203). (in Rus). 